\title{
Productivity of Ospreys, Pandion haliaetus, Affected by Water Levels Near Loon Lake, Saskatchewan, 1975-2002
}

\author{
C. Stuart Houston ${ }^{1}$, Frank ScotT $^{2}$, and Rob B. Tether ${ }^{3}$ \\ ${ }^{1} 863$ University Drive, Saskatoon, Saskchewan S7N 0J8 Canada; E-mail: stuart.houston@usask.ca \\ ${ }^{2}$ Box 2, GS 317, Saskatoon, Saskatchewan S7K 3J6 Canada \\ ${ }^{3}$ Department of the Environment, Unit 1, 101 Railway Place, Meadow Lake, Saskatchewan S9X 1X6 Canada
}

Houston, C. Stuart, Frank Scott, and Rob B. Tether, 2010. Productivity of Ospreys, Pandion haliaetus, affected by water levels near Loon lake, Saskatchewan, 1975-2002. Canadian Field-Naturalist 124(3): 219-224.

Between 1975 and 2002, diminished breeding success of Ospreys was associated with drought and falling lake levels in the western half of our study area near the town of Loon Lake, west-central Saskatchewan. Only $46 \%$ of nest attempts were successful in the west compared to $72 \%$ in the east, producing 0.88 young per accessible nest in the west and 1.42 in the east. Breeding success was greater in the eastern half, where water levels were stable, in spite of increased human use of the resort lakes there. Our unique long-term Canadian data base results support Ogden's 1977 prediction that Osprey productivity may decrease when water levels drop and fish populations are reduced.

Key Words: Osprey, Pandion haliaetus, clutch size, nest success, artificial nest structures, lake water levels, fish populations, Saskatchewan.

Between 1975 and 2002, 463 nestling Ospreys (Pandion haliaetus), a species that relies on fish as food, were raised in summer cottage country near Loon Lake, Saskatchewan. The banding study, which detailed the travels of both adult and young Ospreys, has been published (Houston and Scott 2007).

\section{Methods}

\section{Study Area}

Our Loon Lake study area encompassed 14 named lakes, several smaller water bodies and two First Nation reserves, near the northern ends of highways 21 and 26 in western Saskatchewan (Figure 1) (Scott and Houston 1985, Houston and Scott 2007). Osprey nest occupancy was determined by aerial surveys of adults in an incubation posture during the last week of May or the first week of June, augmented from 1975 through 1990 by weekly flights from Loon Lake to a medical clinic at the Ministkiwan First Nation.

The area and maximum depth of each major lake was determined by Saskatchewan Fisheries Branch employees in 1973 and 1974, with one-time maps of sounding depths throughout each lake (Table 1). Fish populations were sampled then and at roughly 4-year intervals until 1994, using test nets - for example, a $360 \mathrm{~m}$ gill net consisted of $6-60 \mathrm{~m}$ gangs, 3.8 to $14.0 \mathrm{~cm}$ meshes, set in depths ranging from 1.8 to 15.7 m (Dunn 1985*, Durbin 1981-83*, Snell 197379*, Twanow 1986-95*, Wallin 1974-83*).

Hydrology of the two areas is different. A small channel, Ministikwan Creek, that contained no runoff in the years of our study, had the potential in wet years to drain Ministikwan Lake and Branch Lake northeastward into Makwa Lake. The Boa Swamp - Murphy Lake - Fowler Lake chain had water levels maintained by a beaver dam until 1996. The other lakes in the western half drained to the south via Monnery Creek towards the North Saskatchewan River. Together, the western lakes had a small catchment area; most years, evaporation exceeded inflow. The Makwa Lakes in the eastern half of the study area, in contrast, have a larger catchment area, drainage is via the Loon River to the east, and water levels are maintained by the dam on the outlet of the lake into Loon River.

\section{Terminology Regarding Osprey Reproduction}

Terminology is based on Postupalsky $(1974,1989)$ and Steenhof and Newton (2007), with two modifications to allow for less complete surveillance during the incubation period and late fledgling period. A "nestyear" is a nest (territory) occupied in a given year. A nest was successful if one or more young hatched. The term "inaccessible nests" is necessary in Saskatchewan since, unlike Michigan where $97 \%$ of the nestlings could be safely accessed (Postupalsky 1989), up to $21 \%$ of Saskatchewan trees (in 1982-88, see Table 3) were unsafe to climb - and the nestlings in them could not be counted accurately from an airplane. Known causes of nest failure included unhatched (some infertile) and broken eggs, death of all young, starvation, predation, desertion, and nest destruction by high winds. A single annual climb to each accessible nest when the young were two-thirds to four-fifths grown, the age at which most young are banded (Steenhof and Newton 2007), determined the number of nestlings. We calculated the number of young per successful nest and the number per accessible nest, the latter figure including nests that had failed.

\section{Construction of Nest Platforms}

To reduce the high number of inaccessible nest trees, we replaced some of them with platforms during 11 weekends in late March or very early April in 1975, 


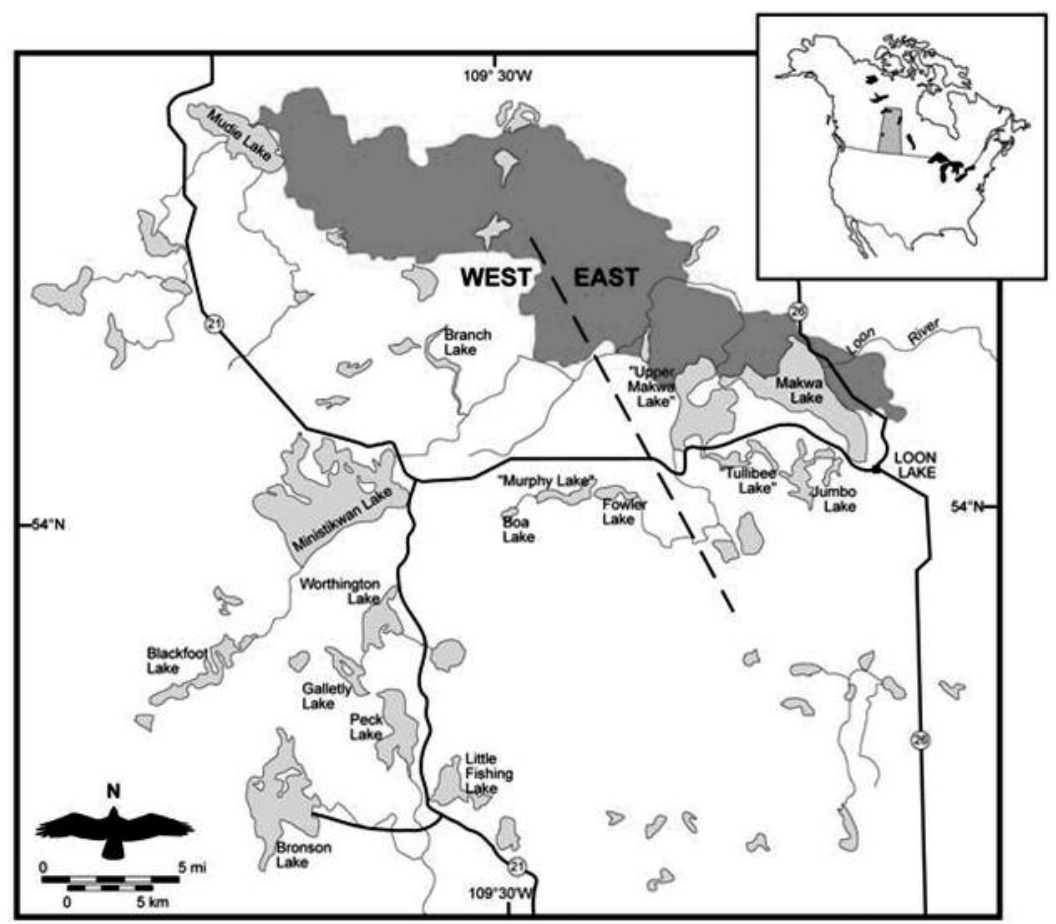

FIGURE 1. Loon Lake area, showing lakes and the demarcation between the West and East components of the area, and the extent of the Mudie Lake fire in 2002. Map by Carol Beaulieu.

1983 to 1990,1992 , and 1994. We felled both dead and live nest trees deemed likely to fall during high winds and then placed the nest contents on the adjacent newly-built platform in a neighbouring tree (Scott and Houston 1985; Houston and Scott 1992, 2007).

\section{Results}

\section{Water levels and fish populations}

In 1975, water levels were high throughout the entire study area. Through 1977, Ministikwan Lake (in the west half of the region and the largest lake in the region), had a thriving winter commercial whitefish harvest of 12,000 to 15,000 kg/yr (Anonymous 1962, $\left.1973^{*}\right)$. For those three years, the western portion of the study area contained the only known occupied and accessible Osprey nests. The first water level decline became evident in 1987 when we could not reach Galletly Lake by boat since the stream from there to Peck Lake had dried up. From 1981 to 1983 there was a poor spring run-off and the level of Ministikwan Lake dropped $45 \mathrm{~cm}$ in 1983 alone (Harrison 1983*). By 1988, the large slough west of Galletly Lake no longer held sufficient water for Frank Scott's float plane to land; in 1990 this large slough was totally dry. At Peck Lake, the commercial whitefish winter fishery was restricted to one month in 1986 and can- celled entirely in 1989, the year that lake levels had dropped $2.8 \mathrm{~m}$ (Twanow 1993a*).

As a consequence, whitefish, walleye and pike populations dropped appreciably. By 1988 few large whitefish remained in Ministikwan Lake, so the commercial harvest that winter was limited to $4500 \mathrm{~kg}$, only onequarter of earlier peak levels, and the daily catch for sport fishing anglers was cut in half from 8 to 4 per day - and has never been restored (Twanow 1988a). In 1987 and 1994, winter-kills of fish occurred in Galletly Lake, the 1994 kill-off being total (Twanow 1994a*). Similar winter fish-kills were reported at Worthington Lake in 1971 and again in 1987-1990, when winter Dissolved Oxygen levels dropped to $1.7 \mathrm{ppm}$ (Twanow 1990a*). At Little Fishing Lake the winter whitefish harvest ceased in 1988 (Twanow 1994b*). At Ministikwan Lake, the 1999 and 2000 seasons were closed early because so few whitefish were being caught; there has been no commercial fishing since (RT).

\section{Osprey Productivity}

a. Clutch Size. Eggs were counted in 42 nests during 4 years: 1988 (June 4 \& 5), 1989 (June 3 \& 4), 1990 (June 2 \& 3) and 1993 (May 29), while trapping adults at selected occupied nests, both west and east, late in incubation when clutches were complete. One 
TABLE 1. Productivity of Ospreys per individual lake in the Loon Lake study area.

\begin{tabular}{|c|c|c|c|c|c|c|c|c|c|}
\hline West Area & Area (ha) & $\begin{array}{c}\max \\
\text { depth } \\
(\mathrm{m})\end{array}$ & $\begin{array}{c}\text { total } \\
\text { occup } \\
\text { nestyrs }\end{array}$ & $\begin{array}{l}\text { access } \\
\text { occup' } \\
\text { nest/yrs }\end{array}$ & $\begin{array}{l}\text { nestyrs } \\
\text { success }\end{array}$ & $\begin{array}{c}\text { \# yg } \\
\text { banded }\end{array}$ & $\begin{array}{c}\text { yg/ } \\
\text { success } \\
\text { nestyr }\end{array}$ & $\begin{array}{c}\mathrm{yg} / \\
\text { access } \\
\text { nestyr }\end{array}$ & $\begin{array}{l}\text { final yr } \\
\text { of use }\end{array}$ \\
\hline Ministikwan Lake & 2554 & 25.6 & 100 & 77 & 26 & 54 & 2.08 & 0.70 & 2000 \\
\hline Bronson Lake ${ }^{\dagger}$ & 1000 & 1.8 & 10 & 8 & 0 & 0 & & & 1989 \\
\hline Blackfoot Lake ${ }^{\dagger}$ & 750 & 1.8 & 2 & 2 & 0 & 0 & & & 1991 \\
\hline Peck Lake & 737 & 14.1 & 54 & 50 & 32 & 61 & 1.91 & 1.22 & 2000 \\
\hline Worthington Lake & 479 & 7.9 & 21 & 21 & 4 & 8 & 2.00 & 0.38 & 1991 \\
\hline Little Fishing Lake & 394 & 29 & 13 & 13 & 10 & 17 & 1.70 & 1.31 & 2000 \\
\hline Branch Lake & 300 & 21 & 34 & 34 & 25 & 53 & 2.12 & 1.56 & 1998 \\
\hline Galletly Lake \& slough ${ }^{\dagger}$ & 232 & 7.6 & 18 & 16 & 6 & 10 & 1.67 & 0.63 & 1988 \\
\hline Murphy (Hoffman) L & 204 & 6.7 & 6 & 3 & 2 & 4 & 2.00 & 1.33 & 1992 \\
\hline Fowler Lake & 130 & 8.2 & 7 & 6 & 2 & 4 & 2.00 & 0.67 & 1990 \\
\hline Moonshine Lake ${ }^{\dagger}$ & 30 & 1.8 & 4 & 3 & 1 & 1 & 1.00 & 0.33 & 1996 \\
\hline Monnery Creek ${ }^{\dagger}$ & 20 & 1.8 & 1 & 1 & 0 & 0 & & & 1989 \\
\hline Boa Swamp $\dagger$ & 20 & 0.8 & 17 & 12 & 4 & 4 & 1.00 & 0.33 & 2001 \\
\hline WEST SUMMARY & 6780 & & 287 & 246 & 112 & 216 & 1.93 & 0.88 & \\
\hline \multicolumn{10}{|l|}{ EAST AREA } \\
\hline Makwa Lake east & 1847 & 23.8 & 115 & 105 & 68 & 124 & 1.82 & 1.18 & $2002 \mathrm{ff}$ \\
\hline Makwa Lake west & 1203 & 26.5 & 35 & 31 & 26 & 53 & 2.04 & 1.71 & $2002 \mathrm{ff}$ \\
\hline Jumbo Lake & 771 & 14.6 & 24 & 13 & 10 & 24 & 2.40 & 1.85 & $2002 \mathrm{ff}$ \\
\hline Tullibee Lake & 259 & 16.8 & 25 & 25 & 21 & 46 & 2.19 & 1.84 & $2002 \mathrm{ff}$ \\
\hline EAST SUMMARY & 4080 & & 199 & 174 & 125 & 247 & 1.98 & 1.42 & \\
\hline GRAND SUMMARY & 10860 & & 486 & 420 & 237 & 463 & 1.97 & 1.10 & \\
\hline
\end{tabular}

${ }^{\dagger}$ indicates smaller water-bodies not used for fishing; depths and areas are approximate

TABLE 2. Summary of reproductive success, comparing the western and eastern halves of the study area with Postupalsky's larger Michigan study (Postupalsky 1989).

\begin{tabular}{|c|c|c|c|c|c|c|c|}
\hline & \multicolumn{7}{|c|}{ Successful nests } \\
\hline & $\begin{array}{c}\text { Number } \\
\text { accessible } \\
\text { attempts }\end{array}$ & $\begin{array}{c}\text { Number } \\
\text { Failed } \\
\text { nests }\end{array}$ & $\begin{array}{c}\text { Number } \\
\text { Success } \\
\text { nests }\end{array}$ & $\begin{array}{l}\text { Percent } \\
\text { Success }\end{array}$ & $\begin{array}{c}\text { Number } \\
\text { Young } \\
\text { banded }\end{array}$ & $\begin{array}{l}\text { Yng/nest } \\
\text { attempt }\end{array}$ & $\begin{array}{c}\text { Yng/ } \\
\text { success } \\
\text { nest }\end{array}$ \\
\hline West & 246 & 134 & 112 & $46 \%$ & 216 & 0.88 & 1.93 \\
\hline East & 174 & 49 & 125 & $72 \%$ & 247 & 1.42 & 1.98 \\
\hline Total & 420 & 183 & 237 & $56 \%$ & 463 & 1.10 & 1.95 \\
\hline Michigan (Postupalsky) & 623 & 253 & 370 & $59 \%$ & 792 & 1.27 & 2.14 \\
\hline
\end{tabular}

TABLE 3. Osprey success by seven-year periods.

\begin{tabular}{|c|c|c|c|c|c|}
\hline & $1975-81$ & $1982-88$ & $1989-95$ & $1996-2002$ & Total \\
\hline \multicolumn{6}{|l|}{ WEST AREA } \\
\hline Unsafe nest-years & 11 & 25 & 4 & 1 & 41 \\
\hline Failed nest-years & 33 & 58 & 31 & 12 & 134 \\
\hline Accessible nest-years & 67 & 93 & 63 & 23 & 246 \\
\hline Successful nest-years & 34 & 35 & 32 & 11 & 112 \\
\hline$\%$ nest success & $51 \%$ & $38 \%$ & $51 \%$ & $48 \%$ & $46 \%$ \\
\hline Young banded & 65 & 69 & 62 & 20 & 216 \\
\hline $\mathrm{Yg} /$ successful nest & 1.91 & 1.97 & 1.94 & 1.82 & 1.93 \\
\hline Yg/accessible nest & 0.97 & 0.74 & 0.98 & 0.87 & 0.88 \\
\hline \multicolumn{6}{|l|}{ EAST AREA } \\
\hline Unsafe nest-years & 1 & 17 & 1 & 6 & 25 \\
\hline Accessible nest-years & 10 & 42 & 58 & 64 & 174 \\
\hline Failed nest-years & 3 & 11 & 14 & 21 & 49 \\
\hline Successful nest-years & 7 & 31 & 44 & 43 & 125 \\
\hline$\%$ nest success & $70 \%$ & $74 \%$ & $76 \%$ & $67 \%$ & $72 \%$ \\
\hline Young banded & 18 & 59 & 89 & 81 & 247 \\
\hline $\mathrm{Yg} /$ successful nest & 2.57 & 1.90 & 2.02 & 1.88 & 1.98 \\
\hline Yg/accessible nest & 1.8 & 1.40 & 1.53 & 1.27 & 1.42 \\
\hline
\end{tabular}




\section{Number of Nestlings Banded}

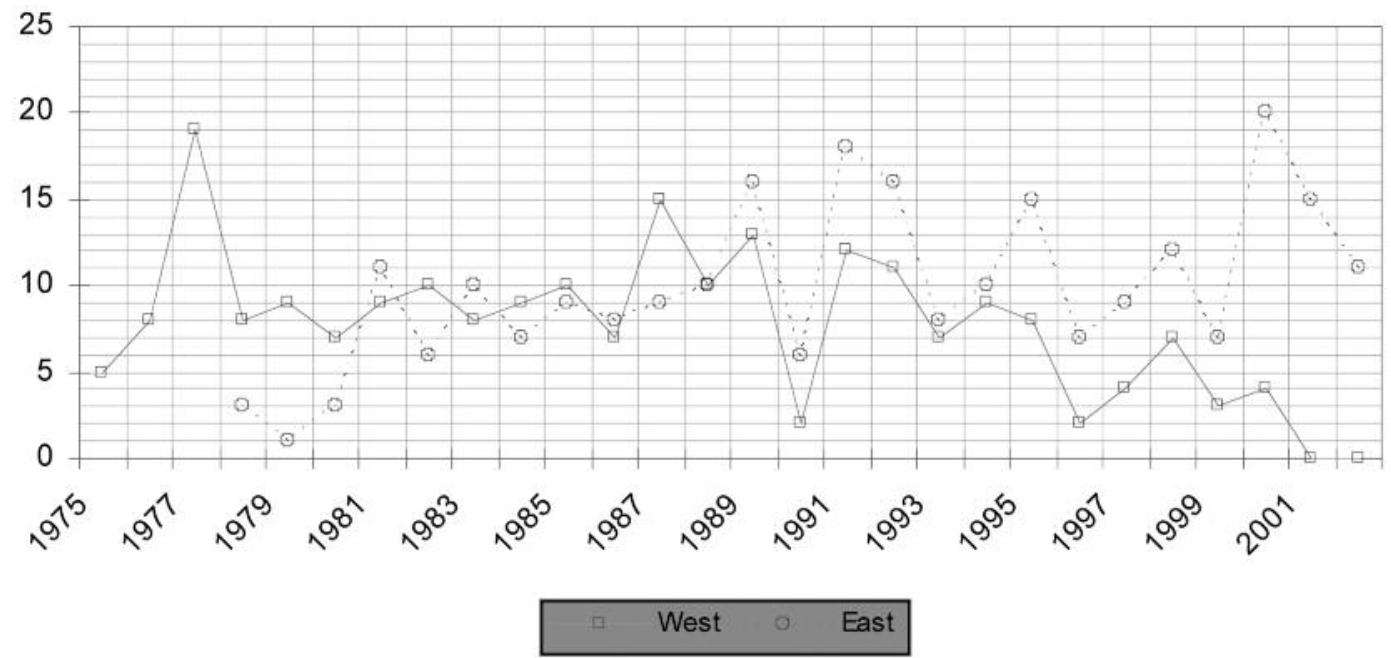

FIGURE 2. Number of successful nests, 1975-2002. In Figures 2 and 3, Squares, joined by solid lines, depict numbers (112 nests, 216 young) in the west half of the Loon Lake study area. Circles, joined by dotted lines, depict the numbers (125 nests, 247 young) in the east half. West: significant decrease over the time of observation, slope $=-0.138, R^{2}=0.305, p=0.002$; East: significant increase over the time of observation, slope $=+0.208, \mathrm{R}^{2}=0.504, \mathrm{p}<0.00001$.

(2\%) had 1 egg, 7 (17\%) had 2 eggs, $31(74 \%)$ had 3 eggs, and $3(7 \%)$ had 4 eggs (mean, 2.8 eggs per clutch). Since 1.95 young in an average nest survived to banding age in mid-July, by using the figure of 2.8 eggs per clutch, we calculated that only about $70 \%$ of the eggs laid resulted in young that survived to banding age.

b. Percent successful nest attempts. There were 246 accessible nest-years in the western half and 174 in the eastern half (Table 1). Only $46 \%$ of nest attempts were successful in the west compared to $72 \%$ in the east (Table 2). [Constructed platforms had a 52\% success rate in the west ( 23 of 44 attempts on 7 platforms) but $72 \%$ in the east (73 of 101 attempts on 10 structures).] The number of successful nests decreased over the period of observation in the west $\left(\mathrm{R}^{2}\right.$ for trend $=$ $0.305, p=0.002)$. However the number of successful nests in the east increased over the same time $\left(\mathrm{R}^{2}\right.$ for trend $=0.504, p<0.00001$ ) (Figure 2).

c. Number of young per accessible nest. In the western half, 0.88 young per accessible nest was far below the 1.42 in the eastern half. Even in the more successful eastern area, the number of young per nesting attempt decreased irregularly over the four 7-year periods, from 1.8 to 1.27 (Table 3). The total number of young banded decreased over the years of observation in the West $\left(\mathrm{R}^{2}\right.$ for trend $\left.=0.280, \mathrm{p}=0.004\right)$. The total number banded in the east increased over the years of observation $\left(\mathrm{R}^{2}\right.$ for trend $\left.=0.320, \mathrm{p}<0.003\right)$.

\section{Discussion}

Ogden (1977) suggested that Ospreys are sensitive to habitat quality and should, therefore, make good biological indicators. This hypothesis was tested by Poole (1982) who found that Florida Osprey nests received $43 \%$ and $11 \%$ fewer fish per day than nests in the two New York colonies, perhaps in part because latitude and season restricted day length and thus foraging time for winter-breeding Florida Ospreys. Bowman et al. (1989) confirmed that the reproductive success of Florida Bay Ospreys after hatching, due to insufficient food resources, was lower than that of birds nesting on adjacent mainline keys, although clutch size was similar. In our Saskatchewan study, we noted that diminishing water levels and decreased fish populations were associated with drastic reductions in Osprey population and breeding success in the western half, in keeping with Ogden's 1977 prediction. In the Loon Lake study area, the more stable water levels in the eastern half acted to some extent as a "control" (Table 1).

\section{Exceptional multi-year productivity at four individual nests}

Favourable local habitat and its selection by unusually successful Ospreys, can in rare instances overcome general trends. In the entire study area, four exceptional nest locations produced many more than their expected share of young, supporting Poole's statement (1989:132) that some Ospreys "are better parents than others." The two most successful Osprey-built nests were paradoxically in the west. Two unusually successful artificial structures were in the east. The two Osprey-built western nests, each at the top of a live spruce, accounted for 41 percent of the nestlings raised among all 51 sites in the west: at Branch Lake North 


\section{Number of Successful Nests}

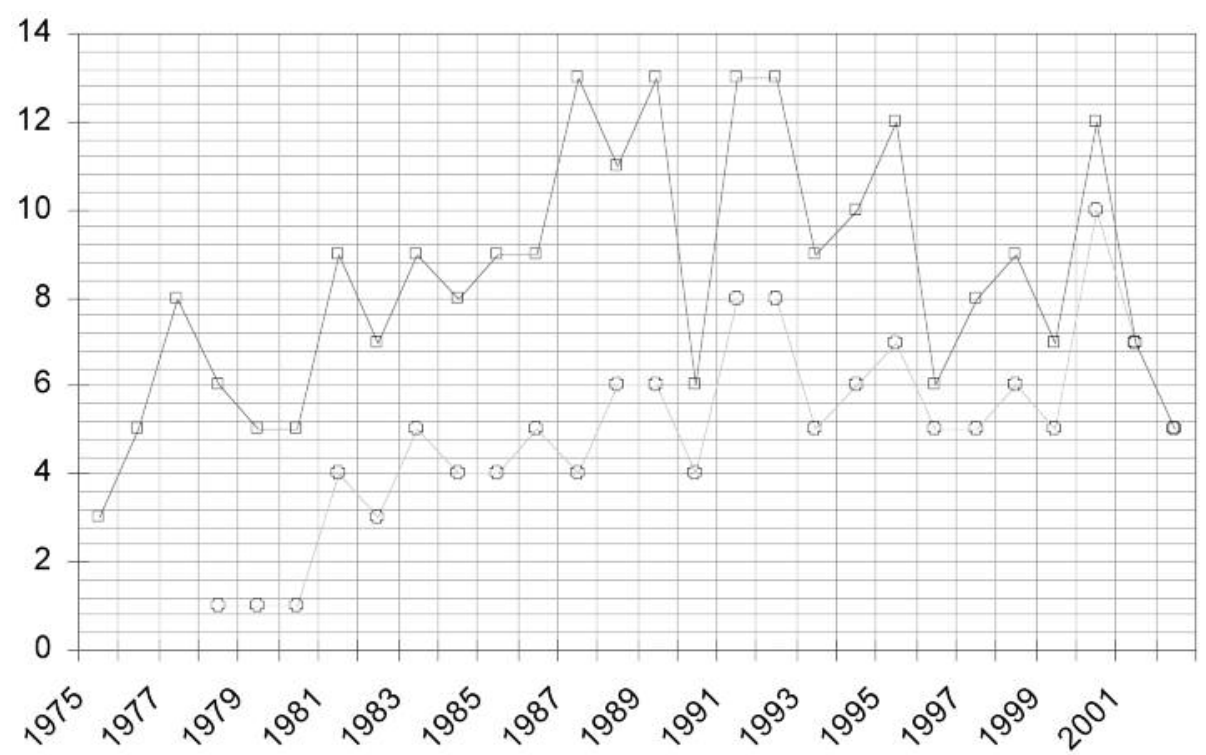

FIGURE 3. Number of nestlings banded each year, 1975-2002. West: significant decrease over the time of observation, slope $=-0.278, \mathrm{R}^{2}=0.280, P=0.004$. East: significant increase over the time of observation, slope $=+0.365, \mathrm{R}^{2}=0.3204$, $P=0.003$.

45 nestlings were produced in 20 successful nesting attempts through 1998 and at the southwest bay of Peck Lake 33 nestlings were raised in 17 successful attempts through 1996. The two most successful human-built structures were both in the east: the platform on the shore of Tullibee Lake, where 26 young fledged in 11 years of success until the nest was usurped in 2001 by a pair of Canada Geese, and the windmill in the marsh south of Jumbo Lake, where 21 young fledged in 9 years of success until the nest failed in 2002, coincident with smoke from massive fire on the other side of the lake.

\section{Effects of human activity}

Ospreys did not seem adversely affected by human activity at these lakes. Over the course of this study, Ospreys decreased at western lakes, which have shortterm campgrounds and a large First Nation reservation, but cottages mainly at Little Fishing and Peck lakes. In the east, Osprey pairs increased at Makwa Lake, a lake used for training provincial water-skiers and the lake with densest cottage use, and at Tullibee Lake, where two families reside. From 1998 until the 2002 fire, most Osprey pairs were concentrated in the mixed forest, mostly jack-pine and spruce, around Tullibee Lake and extending $>1 \mathrm{~km}$ inland from the northern edge of Makwa Lake.

\section{The Mudie Lake Fire, 2002}

The last year of this study, 2002, was noteworthy. A major forest fire, up to $10 \mathrm{~km}$ wide, began at Mudie
Lake, burning the nests, platforms and trees throughout the main Osprey nesting area when it reached the north end of Makwa Lake (Figure 1). Young Ospreys in nests up to $5 \mathrm{~km}$ distant from the fire also perished.

\section{Changing Patterns Since Study}

Since 2002, additional striking changes have occurred to Ospreys in Saskatchewan. There has been a recent southward range extension through Osprey occupancy of power poles over open grassland along the east side of Murray Lake near North Battleford, and of scattered poles and platforms in Aspen Parkland along the North Saskatchewan River (Houston and Scott 2001). At Murray Lake the Ospreys have experienced a new problem: having moved south out of the forest to nest on power poles above large hayfields, the parents bring large quantities of ornamental, colourful baler twine which entangle the legs, wings and necks of nestlings; even one adult died from baler twine around its neck (Houston and Scott 2006).

During our study, Bald Eagles (Haliaeetus leucocephalus), a known Osprey competitor, have moved 50 to $100 \mathrm{~km}$ farther south. At Loon Lake, Bald Eagle populations increased from 0 pairs in 1975 to 1 pair in 1988, 2 pairs in 1990 and 5 pairs in 2010, the year that eagles occupied three nests built and occupied by Ospreys in previous years. Canada Geese (Branta canadensis) have usurped Osprey platforms, but only once did a Canada Goose pair take over an Ospreybuilt nest. 
Comparison of Osprey productivity with other areas

Osprey mean clutch size seems independent of food supply (Poole 1989: 120-121, 219). The mean brood size near fledging, and the number of young produced per successful nest and per occupied nest (Table 2) are similar to similar data from a long-term study in Michigan (Postupalsky 1989).

\section{Acknowledgments}

We thank innumerable tree climbers and platform builders, but especially Marc Bechard, Martin Gerard, David G. Miller, Marten Stoffel, Kelwin Wylie and Dan Zazelenchuk. We are indebted to Marvin Brose for his assistance in locating unused windmills for our use. Alan F. Poole and Marc Bechard provided constructive comment of an earlier version of this paper, Donald S. Houston calculated the regressions, and Sergej Postupalsky, A. J. Erskine, Gary Bortolotti, Joseph K. Schmutz, and two anonymous reviewers must be credited with many recent improvements.

\section{Documents Cited (marked * in text)}

Anonymous. 1962. 1973. Ministikwan Lake Commercial Production Report.

Harrison, T. 1983. Water levels at Ministikwan Lake.

Dunn, C. R. 1985. Sport Fish Management Study, Saskatchewan Fisheries Branch. 1985a. Little Fishing Lake, 25 June 1985; 1985b. Peck Lake, 27 June 1985.

Durbin, J. K. 1981-1983. Recreational Fish Management Study, Saskatchewan Fisheries Branch. 1981a. Little Fishing Lake, 20-21 June 1981; 1983a. Murphy Lake, 8-9 June 1983.

Snell, D. E. 1973-1979. Sport Fish Management Study, Saskatchewan Fisheries Branch. 1973a, 1978a. Big Jumbo Lake, 17-18 September 1973, 28-30 August 1978; 1974a, 1978b. Galletly Lake, 1 March 1974, 1 June 1978; 1973b, 1979a. Ministikwan Lake, 28-30 August 1973, 29 August 1979; 1979b. Peck Lake, 28 August 1979.

Twanow, J. M. 1986-1995. Sport Fish Management Study, Saskatchewan Fisheries Branch: Big and Little Jumbo Lakes, 13 July 1988, 14 June 1994; Branch Lake, 7 June 1989, 23 June 1994; Fowler Lake, 8 June 1989, 17 June 1994; 1986a. Galletly Lake, 1 August 1986, 10 June 1987; 1994a. 21 June 1994; 1994a. Little Fishing Lake, 19 June 1990, 22 June 1994; Makwa Lakes, 14 July 1988, 6 June 1989, 25-26 May 1994; 1988a. Ministikwan Lake History, 1988; Ministikwan Lake, 26 June 1990, 27 June 1995; Murphy Lake, 9 June 1989, 16 June 1994; 1993a. Peck Lake, 31 July 1986, 13 July 1989, 29 June 1993; Tullibee Lake, 3 September 1986, 9 June 1994; 1987a. Worthington Lake, 11 June 1987.
Wallin, L. A. 1974-83. Sport Fish Management Study, Saskatchewan Fisheries Branch: Little Jumbo Lake, 26-27 July 1983; Makwa Lake, 28-29 July 1983; Peck Lake, 1920 June 1974; Tullibee Lake, August 27-28, 1979; Worthington Lake, 25-26 June 1975, 30-31 May 1978, 30-31 May 1983. 1990a. Winter Limnology Report 13 March 1990.

\section{Literature Cited}

Bowman, R., G. V. N. Powell, J. A. Hovis, N. C. Kline, and T. Wilmers. 1989. Variations in reproductive success between subpopulations of the Osprey (Pandion haliaetus) in South Florida. Bulletin of Marine Science 44:245-250.

Houston, C. S., and F. Scott. 1992. The effect of man-made platforms on Osprey reproduction at Loon Lake, Saskatchewan. Journal of Raptor Research 26: 152-158.

Houston, C. S., and F. Scott. 2001. Power poles assist range expansion of Ospreys in Saskatchewan. Blue Jay 59: 182187.

Houston, C. S., and F. Scott. 2006. Entanglement threatens Ospreys at Saskatchewan nests. Journal of Raptor Research 40: 226-228.

Houston, C. S., and F. Scott. 2007. An Osprey banding program near Loon Lake, Saskatchewan, 1975-2002. Blue Jay 65: 133-137.

Ogden, J. C. 1977. A preliminary report of a study of Florida Bay Ospreys. Pages 143-152 in Transactions of the North American Osprey Research Conference. Edited by J.C. Ogden. U.S. National Park Service, Washington, D.C.

Poole, A. 1982. Brood reduction in temperate and sub-tropical Ospreys. Oecologia 53: 111-119.

Poole, A. F. 1989. Ospreys: A Natural and Unnatural History. Cambridge University Press, Cambridge, U.K.

Postupalsky, S. 1974. Raptor reproductive success: some problems with methods, criteria, and terminology. Pages 21-31 in: Management of Raptors. Raptor Research Report Number. 2. Edited by F. N. Hamerstrom, Jr., B. E. Harrell, and R. R. Oldendorff.

Postupalsky, S. 1989. Osprey. Pages 297-313 in Lifetime Reproduction in Birds. Edited by I. Newton. Academic Press, London, England.

Scott, F., and C. S. Houston. 1985. Success of Osprey nest platforms near Loon Lake, Saskatchewan. Blue Jay 43: 238-242.

Steenhof, K., and I. Newton. 2007. Assessing raptor nest success and productivity. Pages 181-191 in Raptor Management and Research Techniques. Edited by D. M. Bird and K. L. Bildstein. Hancock House, Surrey, British Columbia.

Received 20 May 2010

Accepted 12 August 2010 